\title{
CORRECTION
}

View Article Online

View Journal I View Issue

D) Check for updates

Cite this: RSC Adv., 2021, 11, 33300

DOI: $10.1039 / \mathrm{d} 1 \mathrm{ra90156g}$

rsc.li/rsc-advances

\section{Correction: X-ray absorption spectroscopy of exemplary platinum porphyrin and corrole derivatives: metal- versus ligand-centered oxidation}

\author{
Benjamin D. Matson, ${ }^{a}$ Kolle E. Thomas, ${ }^{b}$ Abraham B. Alemayehu, ${ }^{b}$ Abhik Ghosh ${ }^{\star b}$ \\ and Ritimukta Sarangi ${ }^{* a}$ \\ Correction for 'X-ray absorption spectroscopy of exemplary platinum porphyrin and corrole derivatives: \\ metal- versus ligand-centered oxidation' by Benjamin D. Matson et al., RSC Adv., 2021, 11, 32269-32274. \\ DOI: 10.1039/D1RA06151H
}

The authors regret that the one of the author affiliations was incorrectly shown in the original manuscript. The corrected list of affiliations is as shown above.

The Royal Society of Chemistry apologises for these errors and any consequent inconvenience to authors and readers. 